\title{
Severe human rights abuses in healthcare settings
}

\author{
Doctors should be aware of what constitutes torture to avoid being complicit
}

\author{
Lydia Guterman program officer ${ }^{1}$, Martin McKee professor of European public health ${ }^{2}$
}

${ }^{1}$ Public Health Program, Open Society Foundations, New York, NY 10019, USA; ${ }^{2}$ European Centre on Health of Societies in Transition, London School of Hygiene and Tropical Medicine, London WC1H 9SH, UK

Every day healthcare professionals are complicit in serious human rights abuses. Some are the abusers or their assistants, whereas the complicity of others arises from a failure to act on violations that they witness. The responsibilities of doctors in both circumstances should be clear, having been set out by the World Medical Association in the Declaration of Tokyo: "the physician shall not countenance, condone or participate in the practice of torture or other forms of cruel, inhuman, or degrading procedures." Nor shall they "provide any premises, instruments, substances or knowledge to facilitate th[is] practice." Yet, despite clear prohibitions, severe abuses are widespread, even in countries with well developed legal and regulatory systems. ${ }^{2}$

The United Nations Human Rights Committee has specifically identified medical institutions as settings for abuse, ${ }^{3}$ even though the medical personnel involved may be unaware that abuse is occurring. But do abuses in health facilities reach the threshold of torture or cruel, inhuman, or degrading treatment? Often they do. Under international law, any "act by which severe pain or suffering, whether physical or mental, is intentionally inflicted ... by or at the instigation of or with the consent or acquiescence of a public official or other person acting in an official capacity" may be torture or cruel, inhuman, or degrading treatment. ${ }^{4}$ The concept of intent serves to exclude inadvertent suffering, such as that from medical errors.

Serious abuses that are justified by flawed public health arguments are of particular concern. People who use illicit drugs are especially vulnerable to severe abuse-such as lobotomy, beatings, and forced labour - under the guise of treatment for their addiction. ${ }^{5}$ In Vietnam and Laos, ${ }^{67}$ government funded addiction "treatment" comprises incarceration in squalid "rehabilitation" facilities, forced labour, and corporal punishment.

Abuses may arise when cumbersome bureaucratic restrictions keep doctors from providing appropriate care. The preoccupation of officials with drug control at the expense of patient care often translates into insurmountable hurdles to the administration of adequate pain relief. In Ukraine, oral morphine is unavailable, and arbitrary limits on injectable morphine provide only a small fraction of what patients need. ${ }^{8}$ This is contrary to recommendations of the World Health Organization and the
International Narcotics Control Board, and UN experts have stated clearly that denial of pain relief constitutes a failure by governments to protect patients against torture and cruel, inhuman, and degrading treatment. ${ }^{9}$ Reasons for such inadequacies include governments failing to ensure effective systems to procure and distribute analgesics and to provide appropriate training, and misplaced concerns about the risk of patients becoming addicted. Indeed, fear of addiction leads some doctors to perform surgery without anaesthesia on patients with a history of drug dependency. ${ }^{10}$

Pervasive abuses are often dressed up as "good intentions." In many countries, people with disabilities are confined against their will and given treatment without their consent-for example, with neuroleptics. The special rapporteur on torture has said that in some circumstances the suffering inflicted and the effects on the person's health from this forced and non-consensual treatment may constitute a form of torture or ill treatment. ${ }^{11}$ People with physical and intellectual disabilities - along with drug users, women living with HIV, and certain racial and ethnic minorities-are also often forced to undergo permanent sterilisation procedures, often without their consent or even their knowledge. This is a clear violation of the right to be free from torture and ill treatment. ${ }^{12}$

Those who work in healthcare must educate themselves about human rights in medical practice so that they can recognise the problem and be in the front line against abuse in healthcare rather than contributing to it. National regulatory bodies should establish means to identify and act on abuses. International professional bodies could play a greater role. In July 2011 the International Federation of Gynecology and Obstetrics released new guidelines on female contraceptive sterilisation that clearly outlined eligibility and informed consent procedures. In October 2011, the World Medical Association recognised the widespread suffering caused by lack of access to pain relief and adopted a resolution calling on countries to ensure access to essential pain relieving drugs. Much work remains to be done.

Competing interests: Both authors have completed the ICMJE uniform disclosure form at www.icmje.org/coi_disclosure.pdf (available on request from the corresponding author) and declare: $L G$ is the 
coordinator of the Campaign to Stop Torture in Health Care, a coalition of organisations working to combat severe human rights violations in healthcare settings; MMcK is an adviser to the campaign; otherwise, no support from any organisation for the submitted work; no financial relationships with any organisations that might have an interest in the submitted work in the previous three years, no other relationships or activities that could appear to have influenced the submitted work. Provenance and peer review: Not commissioned; externally peer reviewed.

1 World Medical Association. Declaration of Tokyo. Guidelines for physicians concerning torture and other cruel, inhuman or degrading treatment or punishment in relation to detention and imprisonment. 2006. www.wma.net/en/30publications/10policies/c18/index. $\mathrm{html}$

2 Care Quality Commission. Dignity and nutrition inspection programme: national overview. 2011. www.cqc.org.uk/sites/default/files/media/documents/20111007_dignity_and nutrition inspection report.pdf.

3 UN Human Rights Committee. Torture or cruel, inhuman, or degrading treatment or punishment (Art 5). CCPR general comment. No 20. 44th session, 1992. www.ccprcentre. org/doc/lCCPR/General\%20Comments/HRI.GEN.1.Rev.9\%28Vol.1\%29_\%28GC20\%29 en.pdf.

4 United Nations General Assembly. Convention against torture and other cruel, inhuman or degrading treatment or punishment. 1987. http://treaties.un.org/untc//Pages//doc/ Publication/UNTS/Volume\%201465/volume-1465-I-24841-English.pdf.
5 Open Society Foundations. Human rights abuses in the name of drug treatment: reports from the field. OSF, 2010.

6 Human Rights Watch. The rehab archipelago: abuses in Vietnam drug detention centers. 2011. www.hrw.org/features/rehab-archipelago-abuses-vietnam-drug-detention-centers.

7 Human Rights Watch. Somsanga's secrets: arbitrary detention, physical abuse, and suicide in a Lao drug detention center. 2011. www.hrw.org/sites/default/files/reports/ laos 1011 webwcover 0 .pdf.

8 Human Rights Watch. Uncontrolled pain: Ukraine's obligation to ensure evidence-based palliative care. 2011. www.hrw.org/sites/default/files/reports/ukraine0511WebRevised. pdf.

9 Nowak M. Report of the special rapporteur on torture and other cruel, inhuman or degrading treatment or punishment. 2009. www2.ohchr.org/english/bodies/hrcouncil/docs/10session/ A.HRC.10.44AEV.pdf.

10 Public Association "Aman Plus." Observance of the rights of people who use drugs to obtain health care in the Kyrgyz Republic. Open Society Institute and Soros Foundation Kyrgyzstan, 2008. www.soros.org/initiatives/health/focus/law/articles_publications/ publications/kyrgyz_20081120/aman_20081120.pdf.

11 Nowak M. Interim report of the special rapporteur on torture and other cruel, inhuman or degrading treatment or punishment. 2008. www.unhcr.org/refworld/pdfid/48db99e82.pdf.

12 Center for Reproductive Rights. Reproductive rights violations as torture and cruel, inhuman, or degrading treatment or punishment: a critical human rights analysis. 2010. http://reproductiverights.org/sites/crr.civicactions.net/files/documents/TCIDT.pdf.

Cite this as: BMJ 2012;344:e2013

(c) BMJ Publishing Group Ltd 2012 